\title{
Catechin and Epicatechin Contents in Wines Obtained from Brazilian Exotic Tropical Fruits
}

\author{
Suyare Araújo Ramalho*, Nayjara Carvalho Gualberto, Maria Terezinha Santos Leite Neta, \\ Rejane Andrade Batista, Suzane Macêdo Araújo, Jane de Jesus da Silveira Moreira, \\ Narendra Narain
}

Laboratory of Flavor \& Chromatographic Analyses/PROCTA, Federal University of Sergipe, São Cristóvão, Brazil. Email: suyare@gmail.com

Received January $3^{\text {rd }}, 2014$; revised February $3^{\text {rd }}$, 2014; accepted February $10^{\text {th }}$, 2014

Copyright (c) 2014 Suyare Araújo Ramalho et al. This is an open access article distributed under the Creative Commons Attribution License, which permits unrestricted use, distribution, and reproduction in any medium, provided the original work is properly cited. In accordance of the Creative Commons Attribution License all Copyrights (C) 2014 are reserved for SCIRP and the owner of the intellectual property Suyare Araújo Ramalho et al. All Copyright (C) 2014 are guarded by law and by SCIRP as a guardian.

\section{ABSTRACT}

Flavonoids constitute a diverse group of secondary metabolites which are present in both fruits and wines. The contents of some of the most prominent compounds such as catechin and epicatechin are little known in wines prepared from tropical fruits. In this context, this study was aimed to determine catechin and epicatechin contents in wines processed from 7 tropical fruits (cajá-umbu, cashew apple, mangaba, pineapple, siriguela, sugar apple and umbu), by HPLC-DAD system. Moreover the total phenolic compounds content was also determined in these wines and compared to those of the commercial wines obtained from grapes and cashew apple. The wines produced in this work contained higher total phenolic compounds contents when compared to that of the grape wines. The higher values of total phenolic compounds were found in wines elaborated from cajá-umbu (123.4 $\left.\mathrm{mg} \cdot \mathrm{mL}^{-1} \mathrm{GAE}\right)$ and from cashew $\left(87.5 \mathrm{mg} \cdot \mathrm{mL}^{-1} \mathrm{GAE}\right)$. However, higher contents of catechin and epicatechin were found in wines obtained from mangaba $\left(14.01 \pm 0.37 \mathrm{mg} \cdot \mathrm{L}^{-1}, 22.66 \pm 1.03 \mathrm{mg} \cdot \mathrm{L}^{-1}\right)$, siriguela $(9.97$ $\pm 0.28,4.38 \pm 0.45)$ and cashew apple $(7.46 \pm 0.18,1.30 \pm 0.17)$ fruits. The present work indicates that the use of exotic tropical fruits is feasible in developing wines which could serve as functional foods as these contain appreciable quantities of catechin and epicatechin.

\section{KEYWORDS}

\section{Tropical Fruits; Cajá-Umbu; Mangaba; Cashew Apple; Siriguela; Wines; HPLC-DAD}

\section{Introduction}

In recent years, the demand for nutraceutical products which contribute to good human health, has led major food companies develop alternative products containing functional substances. The flavonoids are the most abundant polyphenols which contain two or more aromatic rings connected to at least one aromatic hydroxyl group and a bridge of carbon. Of late these compounds have been the subject of many studies since these are identified with health benefits, ranging from prevention of caries to cancer. Much has been said about the functionality of these compounds that have anti-carcinogenic, antiatherogenic, anti-thrombotic, anti-microbial, and anal-

${ }^{*}$ Corresponding author. gesic vessel dilator effects [1,2]. Some studies regarding the functionality of these compounds relate to their presence in green tea, fruits, vegetables and wines which possess large amounts of flavonols, antioxidant substances that fight free radicals [3].

Although colorless or slightly yellowish, the flavonoids have an important role in strengthening and stabilizing the color of red wines. They contribute to the sensory characteristics such as taste, astringency and harshness of wine, in addition, to the preservation of the beverages and retaining properties of the wine aging process. Most phenols are in the form of tannins (molecules which preserve the wine by absorbing oxygen) or as flavonoid derivatives such as flavan-3-ols and flavan-3,4diols which can polymerize tannins. The most important 
representatives of the group of flavan-3-ols are the catechin and epicatechin, epimers at carbon 3 (Figure 1) [4]. According to Teissedre et al. [5], among the various phenolic compounds present in wines, the greatest antioxidant activity in preventing LDL oxidation was imparted by flavan-3-ols such as catechin, epicatechin, dimers and trimers of procyanidins, which characterize for highest antioxidant activity [5].

The epicatechin has not only a direct antioxidant effect but also is able to conserve other antioxidants such as vitamins C and E. According to Auger et al. [6], small amounts, such as $1 \mathrm{mM}$ of epicatechin are good enough for vitamins $\mathrm{C}$ and $\mathrm{E}$, to be protected from oxidation. Moreover, the catechins present in plants and fruits are the main therapeutic, free radical scavengers, metal chelators, inhibitors to DNA damage by ROS in skin inflammation and immune suppression induced by UV rays. Catechins and procyanidins have characterized to be potent inhibitors of LDL oxidation than $\alpha$-tocopherol. Among the factors that explain this fact is the ease of flavonoids in capturing free radicals in the blood. When lipid peroxidation begins or occurs, the flavonoids may prevent the reaction by limiting the initial phase [7].

Due to the great diversity of metabolic processes in the formation of flavanol substances and of their similar chemical characteristics, it is difficult to estimate their quantitative content in plant tissues in an absolute manner. However, HPLC technique can provide different retention times to allow the identification of these compounds [8]. Typically, each specie is associated with a particular family of polyphenols, the contents of which increase with age and vary with the vegetative development of fruit. Catechins and epicatechins are mainly present in grape seeds and are the main phenolic compounds responsible for flavor and astringency of wine and grape juice, however, some studies have revealed the presence of these flavanols in other vegetable matrices [9-11]. The Brazil and in particular the North and Northeast regions are recognized as producers of exotic tropical fruits, whose high perishability requires the development of technologies for new products and thus reduce post-harvest losses. Studies show that fermented fruit drinks have been highlighted as better means of using these fruits, not only by having attractive sensory characteristics in products, but also because they are natural sources of phenollic compounds, substances which possess anti-inflammatory, antimicrobial and anticarcinogenic activities [2, 3]. However, there are no reports yet published on the contents of some flavonoid compounds present in wines obtained from exotic tropical fruits. Thus this study had an objective to produce wines from exotic tropical fruits (cajá-umbu, cashew apple, mangaba, pineapple, siriguela, sugar apple and umbú) and to identify and quantify catechin and epicatechin present in these wines, using a HPLC-DAD system. The results were further compared with their presence in some commercial wines such as Grape Merlot, Green Grape and Cashew apple.

\section{Material and Methods}

\subsection{Chemicals and Standards}

Acetonitrile and acetic acid of HPLC-grade were obtained from Merck (São Paulo, Brazil). Standards of (+) catechin, (-) epicatechin were bought from Sigma (São Paulo, Brazil). Sacharomyces cerevisae was used in wine fermentation as yeast starter and it's commercial lyophilized form was used (Dr. Oetker Brazil Ltda, São Paulo, Brazil). Working solutions of each standard $\left(0.5 \mathrm{mg} \cdot \mathrm{mL}^{-1}\right)$ were prepared by dilution with MilliQ water. The wine samples were kept in amber bottles in a refrigerator $(24 \mathrm{~h}$ at $\left.4^{\circ} \mathrm{C}\right)$, filtered and prepared by dissolving $1 / 5(\mathrm{v} / \mathrm{v})$ with distilled water.

\subsection{Must and Wine Preparation}

Tropical fruits used in this study were purchased from Central Market in the city of Aracaju, Brazil. The cashew apple (Anacardium occidentale L.), umbu (Spondias

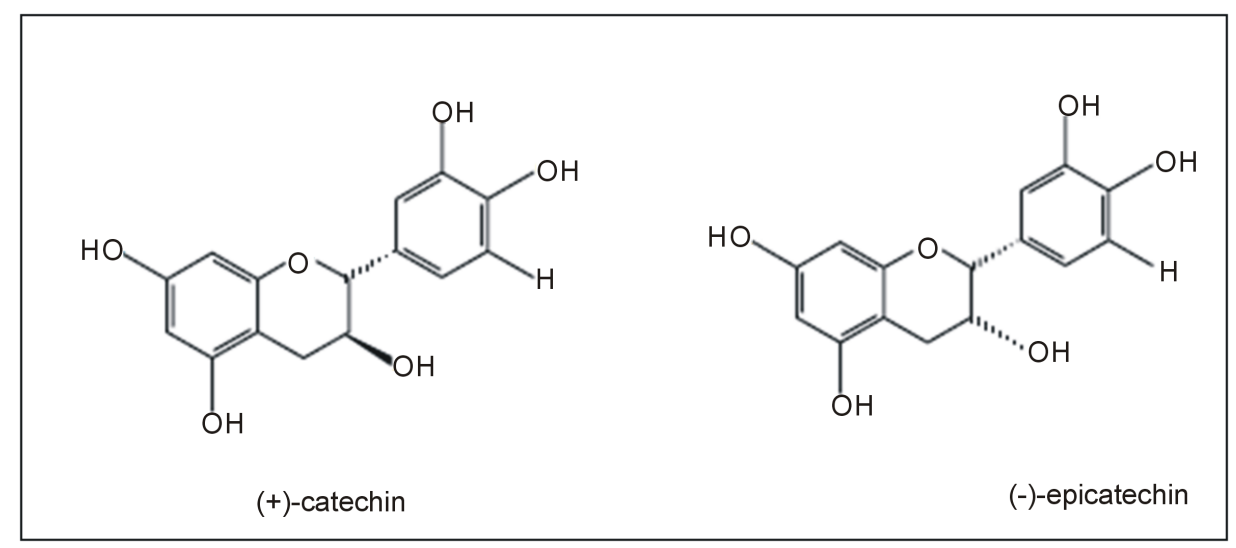

Figure 1. Structures of catechin and epicatechin. 
tuberosa Arruda Camara), cajá-umbu (Spondias spp.), siriguela (Spondias purpurea L.), mangaba (Hancornia speciosa Gomes), pineapple (Ananas comosus L.) and sugar apple (Annona squamosa L.) fruits were used in preparing wines (Figure 2). The fruits at the optimal stage of ripening were selected and processed. The fruits were sanitized with sodium hypochlorite $0.66 \%$ during $10 \mathrm{~min}$, processed and filtered to obtain clarified juice. The must was prepared by mixing with sucrose so as to obtain $30^{\circ}$ Brix and other chemical solutions such as 1 $\mathrm{g} \cdot \mathrm{L}^{-1}$ ammonium phosphate (Vetec Fine Chemical Ltda, Duque de Caxias-RJ, Brazil), $0.1 \mathrm{~g} \cdot \mathrm{L}^{-1}$ of magnesium sulfate (Labsynth Ltda, Diadema-SP, Brazil), $0.1 \mathrm{~g} \cdot \mathrm{L}^{-1}$ of sodium metabissulfite (Vetec Fine Chemical Ltda, Duque de Caxias-RJ, Brazil) and citric acid (Cromato Ltda, Diadema-SP, Brazil) solution, $10 \%$ to adjust its $\mathrm{pH}$ to 4.0. The must was then sterilized in an autoclave at $121^{\circ} \mathrm{C}$ under $1 \mathrm{~atm}$ pressure for $20 \mathrm{~min}$. A volume of 18 $\mathrm{mL}$ of culture was transferred to $250 \mathrm{~mL}$ Erlenmeyer flask containing $180 \mathrm{~mL}$ of juice, and it was incubated under identical conditions of pre-inoculum for $12 \mathrm{~h}$, yielding a count of $10^{7}$ cells $\cdot \mathrm{mL}^{-1}$. The commercial wines (Merlot grape, Cashew apple and Green grape) were obtained from a wine shop.

\subsection{Fermentation Process}

One liter of fruit juice was taken in an Erlenmeyer flask and $10 \%$ inoculum volume was added. The flasks were maintained at room temperature $\left(30^{\circ} \mathrm{C} \pm 3^{\circ} \mathrm{C}\right)$ without any agitation until its Brix got stabilized, considering a maximum variation of 0.20 . The fermentation was car-

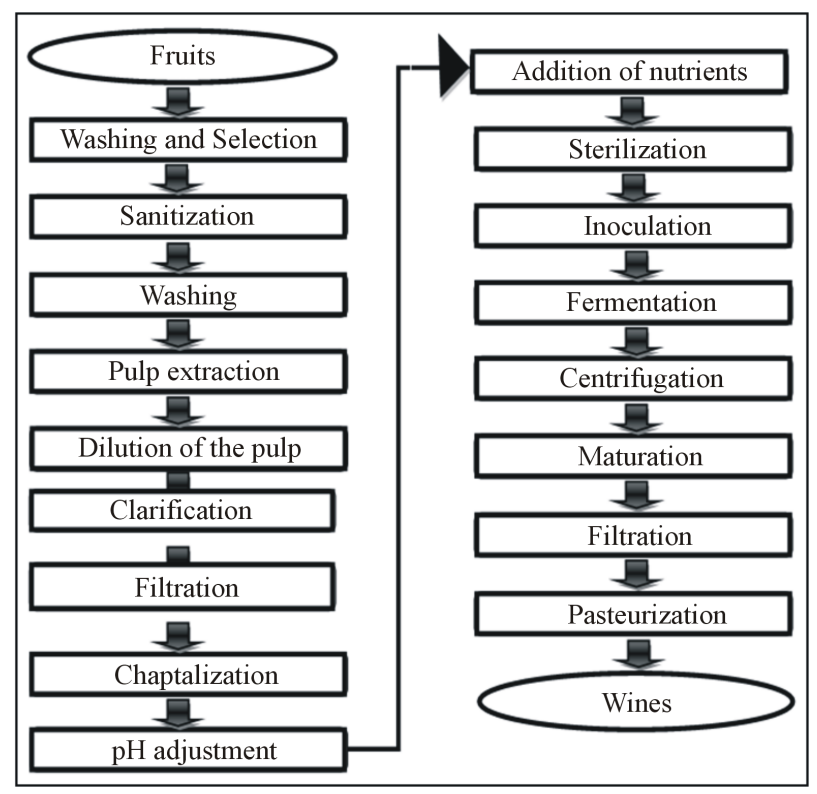

Figure 2. Flow diagram of the fermentation process for preparation of wines using exotic tropical fruits. ried out according to the detailed methodology presented by Araujo et al. [12]. Following fermentation, the flasks were stored under refrigeration $\left(4^{\circ} \mathrm{C}\right)$ for $24 \mathrm{~h}$ for the solid-phase separation. Later the fermented product was centrifuged at $3000 \times \mathrm{g}$ for $5 \mathrm{~min}$, so as to facilitate separation and the solid material was removed by filtration. Later, the liquid was again filtered under the same conditions followed by its filling in sterilized wine bottles $(750 \mathrm{~mL}$ capacity), which were sealed and pasteurized at $60^{\circ} \mathrm{C} \pm 5^{\circ} \mathrm{C}$ for $30 \mathrm{~min}$, followed by cooling to $20^{\circ} \mathrm{C}$ for $10 \min$ [12].

Commercial wines produced from using grapes (Vinyls vinífera), green grapes and cashew apple fruits (Anacardium occidentale L.) were also analyzed. The Figure 2 shows the flow diagram of the fermentation process for preparation of wines using exotic tropical fruits.

\subsection{Chromatographic Analysis}

\subsubsection{Extraction}

The wines samples were stored at $4^{\circ} \mathrm{C}$, filtered through a filter paper whatman no. 1 . The samples were then diluted in ultrapure water (1:5), filtered again on nylon filters of $0.45 \mu \mathrm{m}$.

\subsubsection{Separation and Identification}

The compounds such as $(+)$ hydrated catechin and $(-)$ epicatechin were identified and determined in wines and fermented samples by using a HPLC system (LC-20A, Shimadzu, Japan) according to the methodology reported by Viñas et. al. [13]. This system comprised of a quaternary pump (LC-20AT), an autosampler (SIL-20A), a degasser (DGU-20A) and a Diode Array Detector (UV/ VIS-DAD, SPD-M20A) using the wavelength of $280 \mathrm{~nm}$. The catechin and epicatechin were separated on C18 column $(4.6 \mathrm{~mm} \times 250 \mathrm{~mm}, 5 \mu \mathrm{m}$, Shimadzu) with gradient elution of two mobile phases (flow $1 \mathrm{~mL} \cdot \mathrm{L}^{-1}$ ). The mobile phase consisted of (A) acetonitrile and (B) acetic acid, the gradient mode consisted of $9 \%$ acetonitrile (A) for $10 \mathrm{~min}$; $25 \%$ of solvent A until $11 \mathrm{~min}$, later, $70 \%$ of solvent A by 1 min until 5 min, returning the initial condition by 1 min until $15 \mathrm{~min}$. A $20 \mu \mathrm{L}$ volume was injected. Wine samples $(1 \mathrm{~mL})$ were filtered in filter paper (Whatman no. 5) and diluted in $5 \mathrm{~mL}$ of distilled water. The standards $(0.00325$ to $0.5 \mathrm{ng} / \mathrm{mL})$ were injected directly into the column. All measurements were performed in quadruplicate $(n=4)$ and their mean and standard deviation values calculated. The $(+)$ catechin and (-) epicatechin peaks were identified by the comparison of retention times and UV spectra with commercial standards of these phenolic compounds. Chromatograms were analyzed with the LC Solution (Shimadzu) software and quantification was done by using linear regression analysis and calibration curves prepared for individual 
compounds.

\subsection{Extraction of Phenolic Compounds}

The extraction and fractionation of phenolic compounds were carried out using established methods [14,15] with some modifications [16]. All analyses were performed in quadruplicate using a standard gallic acid solution at the following concentrations (25, 50, 75, 100, 125, 150, 175 and $200 \mathrm{mg} / \mathrm{mL}$ ). The determination of total phenolic compounds in wines was made by measuring the absorbance in UV/VIS 1240 spectrophotometer (Shimadzu Corporation, Japan) at a wavelength of $725 \mathrm{~nm}$ in the standard solutions and extracts obtained from fermented beverages after reacting with Folin-Ciocalteu reagent.

\subsection{Statistical Analysis}

The concentrations of catechin and epicatechin were measured and analyzed using the simple regression analysis and analysis of variance (ANOVA) in quadruplicate $(n=4)$. Mean concentration and standard deviation data were reported.

\section{Results and Discussion}

During the process of wine preparation significant changes take place in the composition and content of phenolic compounds resulting from the process of fruit disintegration as well as fermentation and ageing [17].

The Figure 3 shows the total phenolic compounds content of seven wines produced using exotic tropical fruits along with those of the three commercial wines (grape and cashew apple). The cajá-umbu wine contained higher total phenolic compounds (123.41 mg. $\mathrm{mL}^{-1} \mathrm{GAE}$ ) than other wines elaborated in laboratory.

However, the commercial grape wine Merlot obtained the highest value $\left(146.0 \mathrm{mg} \cdot \mathrm{mL}^{-1} \mathrm{GAE}\right)$ among all the wines analyzed. According to Czyzowska \& Pogorzelski [18], the phenolic compound accumulation in wine may derive from the enzymatic reaction, yeast fermentation, and oxidative polymerization reactions but it depends also on the fruit that is processed. In case of white wines which do not contain anthocyanins, the total phenolic compounds content is low when compared with red and darks wines [18]. This can be explained because red wine is rich in anthocyanins and soluble and hydrolysable tannins that represent condensed form of flavonoids [19]. This fact was also verified in this study based on the data obtained from wines produced from pineapple, mangaba and green grapes as these wines were of clarified colors and showed lower quantities of total phenolic compounds (34.43, 44.3 and $42.04 \mathrm{mg} \cdot \mathrm{mL}^{-1} \mathrm{GAE}$, respectively) among all the wines analyzed in this study.

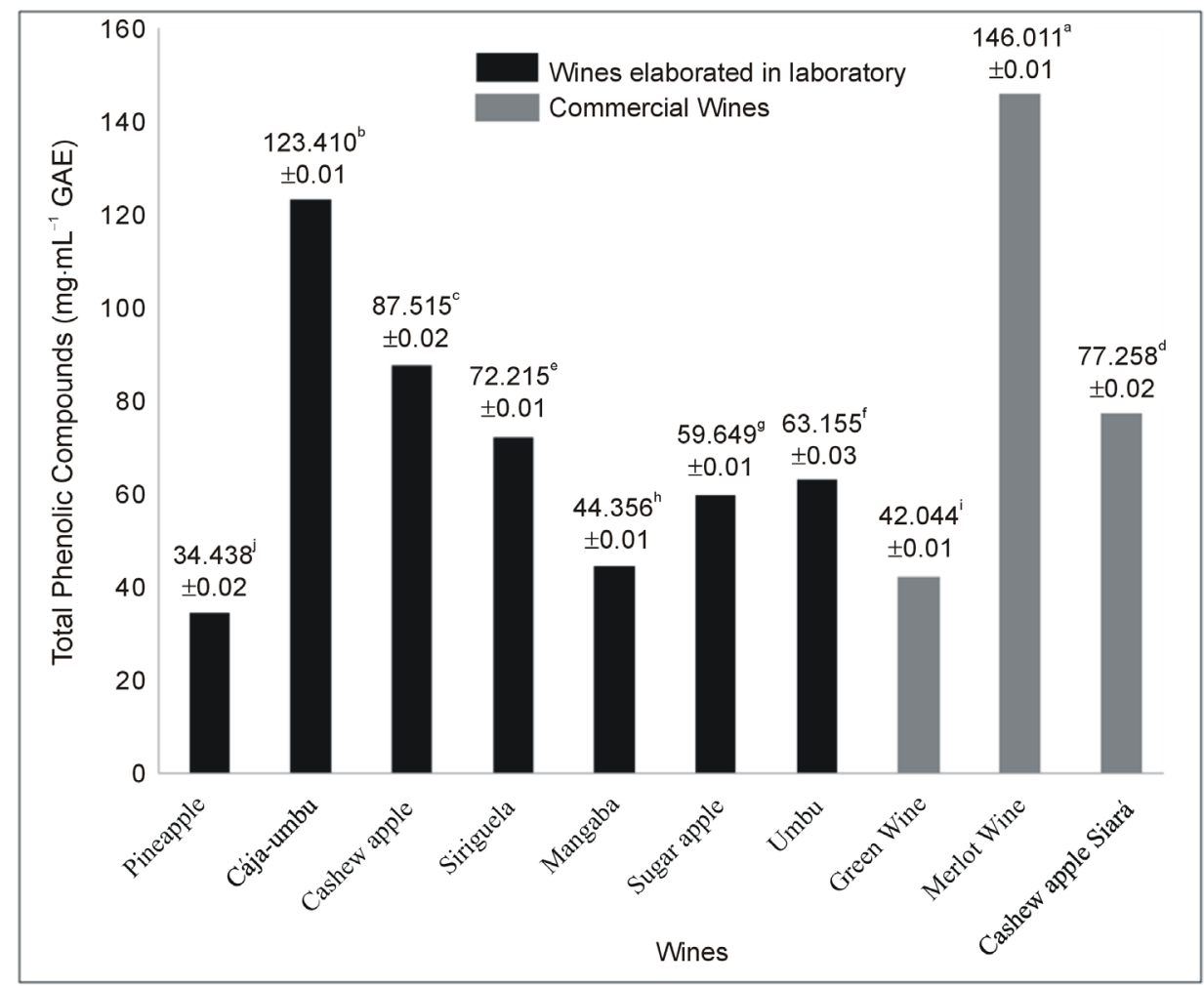

Figure 3. Total phenolic compounds contents in wines of tropical fruits elaborated in laboratory and commercial wines. Different superscripts for mean values represent the significant difference $(p<0.05)$. 
The presence of compounds such as catechin and epicatechin in wines is important to wine producer, as it plays an important role in the anti-oxidant capacity of both juice and wines. Moreover, low molecular weight catechin could significantly participate in the antioxidant capacity of red wine and it could directly be correlated with its concentration [20]. The Figure 4 shows the various chromatograms obtained on analysis of the wines produced from tropical fruits along with those of the commercial samples. The focus on identification was on the compounds catechin and epicatechin.

The data presented in Table 1 were determined by the equations $y=2 E+07 x-19966\left(R^{2}=0.9989\right), y=5 E+$ $06 x+1125.3\left(R^{2}=0.9957\right)$ obtained by the calibration curves prepared by using the standards $(+)$ hydrated catechin (Sigma-Aldrich, 98\%) and (-) epicatechin (Sigma-Aldrich, 98\%), respectively. The largest concentration among the two phenolic Compounds determined in the wines of tropical fruits (Figure 4) was that of catechin. Among the 9 wines elaborated in the laboratory (Table 1), the highest concentrations of catechin (14.01 $\left.\mathrm{mg} \cdot \mathrm{L}^{-1}\right)$ and epicatechin $\left(22.66 \mathrm{mg} \cdot \mathrm{L}^{-1}\right)$ were found in mangaba wine while lower concentrations of these compounds were in sugar apple wine $\left(4.34\right.$ and $4.11 \mathrm{mg} \cdot \mathrm{L}^{-1}$ to catechin and epicatechin, respectively).

The catechin contents of all wines (prepared in laboratory and commercial products) were found to be significantly different $(\mathrm{p}<0.05)$. The epicatechin contents did not differ significantly among umbu, caja-umbu and grape merlot wines as also the values were similar among the pineapple, siriguela and sugar apple wines (Table 1).

Table 1. Catechin and epicatechin contents (mean \pm standard deviation values) in various wines obtained from the use of tropical fruits.

\begin{tabular}{|c|c|c|}
\hline \multirow{2}{*}{$\begin{array}{l}\text { Wines elaborated in } \\
\text { Laboratory from fruits and } \\
\text { commercial products }\end{array}$} & \multicolumn{2}{|c|}{$\begin{array}{c}\text { Concentration of Flavonols } \\
\left(\mathrm{mg} \cdot \mathrm{L}^{-1}\right)\end{array}$} \\
\hline & Catechin & Epicatechin \\
\hline Umbu & $5.48 \pm 0.12^{f}$ & $2.19 \pm 0.21^{\mathrm{d}}$ \\
\hline Cajá-umbu & $4.78 \pm 0.04^{\mathrm{g}}$ & $2.53 \pm 0.25^{d}$ \\
\hline Pineapple & $6.76 \pm 0.17^{e}$ & $4.07 \pm 0.11^{b c}$ \\
\hline Siriguela & $9.97 \pm 0.28^{b}$ & $4.38 \pm 0.45^{b}$ \\
\hline Cashew apple & $7.46 \pm 0.18^{d}$ & $1.30 \pm 0.17^{\mathrm{e}}$ \\
\hline Mangaba & $14.01 \pm 0.37^{\mathrm{a}}$ & $22.66 \pm 1.03^{\mathrm{a}}$ \\
\hline Sugar apple & $4.34 \pm 0.05^{h}$ & $4.10 \pm 0.49^{\mathrm{bc}}$ \\
\hline Grape merlot & $9.39 \pm 0.10^{c}$ & $2.50 \pm 0.09^{\mathrm{d}}$ \\
\hline Cashew apple Siará & $3.99 \pm 0.26^{\mathrm{i}}$ & $0.14 \pm 0.07^{\mathrm{f}}$ \\
\hline Green grape & $3.19 \pm 0.02^{j}$ & $3.71 \pm 0.41^{\mathrm{c}}$ \\
\hline
\end{tabular}

${ }^{\mathrm{A}} \mathrm{N}=4$; Different superscripts within the same column for each value mean significant difference $(\mathrm{p}<0.05)$.
The highest contents of both these compounds were found in wine prepared from mangaba fruit. No data have yet been published in literature which reports the presence of these compounds in wines obtained from the use of these tropical fruits.

Monagas et al. [1] reported that the catechin content in wines could increase on storage until 12 months. However, the flavonols content depends not only on the storage period, but it also gets effected by season, variety, environmental and climatic conditions, plant disease, geographic locations and even maturity in the matrix seems to play an important role in the concentration of phenolic compounds present in fermented beverages [21-23]. This could as well explain the difference in the data on these compounds in cashew apple wines as the commercial wine prepared from cashew apple fruits had lower levels of catechin $\left(3.99 \mathrm{mg} \cdot \mathrm{L}^{-1}\right)$ when compared with the cashew apple wine prepared in the laboratory (7.46 mg. $\mathrm{L}^{-1}$ and $1.30 \mathrm{mg} \cdot \mathrm{L}^{-1}$ of catechin and epicatechin, respectively). Besides, high levels of catechin and epicatechin found in homemade wines may be related to the handmade process and hence the absence of substances used by industrial wineries such as polyvinylpolypyrrolidone what acts on the catechin and epicatechin, inhibiting them [24].

In young red grape wines, the concentrations of catechin and epicatechin were found to vary from $4.96-7.14$ $\mathrm{mg} \cdot \mathrm{L}^{-1}$ and $2.02-3.02 \mathrm{mg} \cdot \mathrm{L}^{-1}$ which were very similar to the data found in tropical fruits wines in this study with the exception of mangaba wine, which contained higher values (14.01 and $22.66 \mathrm{mg} \cdot \mathrm{L}^{-1}$ of catechin and epicatechin, respectively) [25]. Blanco et al. [26] reported comparable levels of catechin $\left(6.8 \mathrm{mg} \cdot \mathrm{L}^{-1}\right)$ and epicatechin $\left(1.5 \mathrm{mg} \cdot \mathrm{L}^{-1}\right)$ in red grape's wines, but, according to Gurbuz et al. [8] in the wines samples, the catechin was found to be the highest in red Boğazkere wine $\left(14.357 \mathrm{mg} \cdot \mathrm{L}^{-1}\right)$.

In white wines where there is a limited contact with the skins, the catechins are the main flavonoids. These compounds are responsible for the browning of white or red wines and result also in some bitterness. This happens because flavanols are involved in enzymatic browning reactions and their interaction with proteins results in the turbidity of the beverages [7].

In winemaking, the catechins are transferred to the must in the soaking step. However, during the manufacture of white wine, there is a quick press operation to separate peel and pulp which explains the fact that the low amount of phenolic compounds are present in white wines [6] (Table 2).

The Table 2 presents the data on some commercial wines analyzed in laboratory (Merlot and Green grape) along with the published data, showing the proximity of the results obtained in this study. 


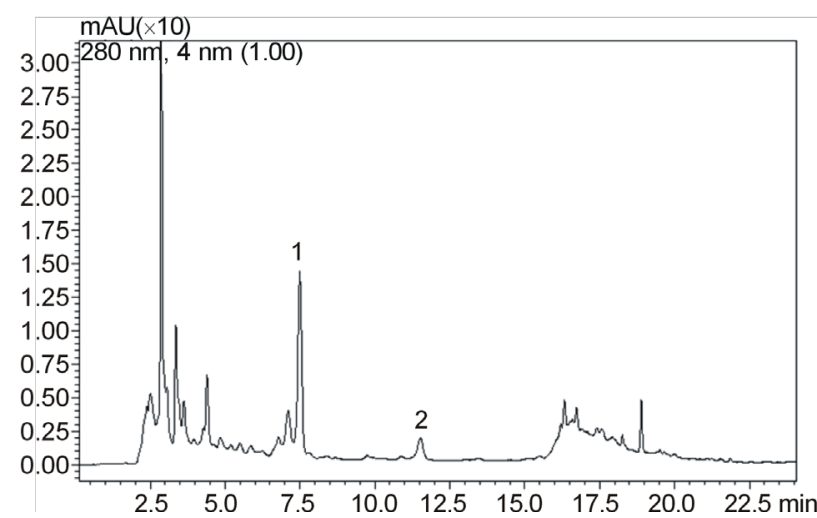

(a)

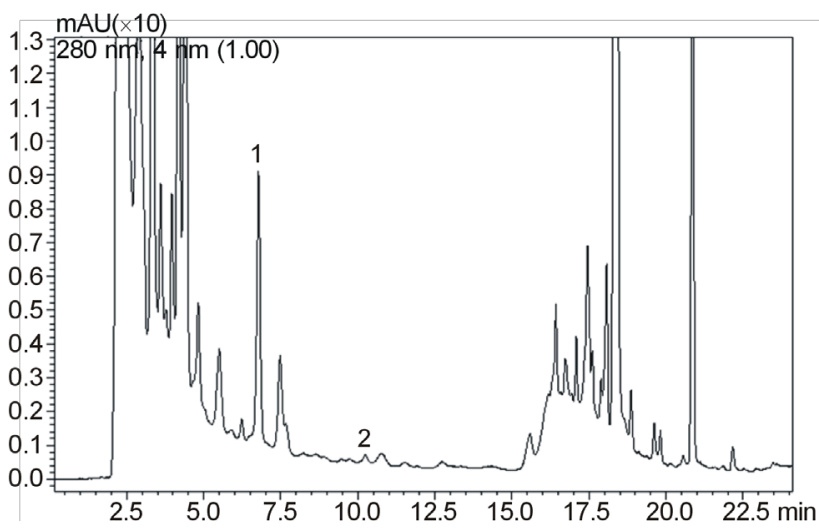

(c)

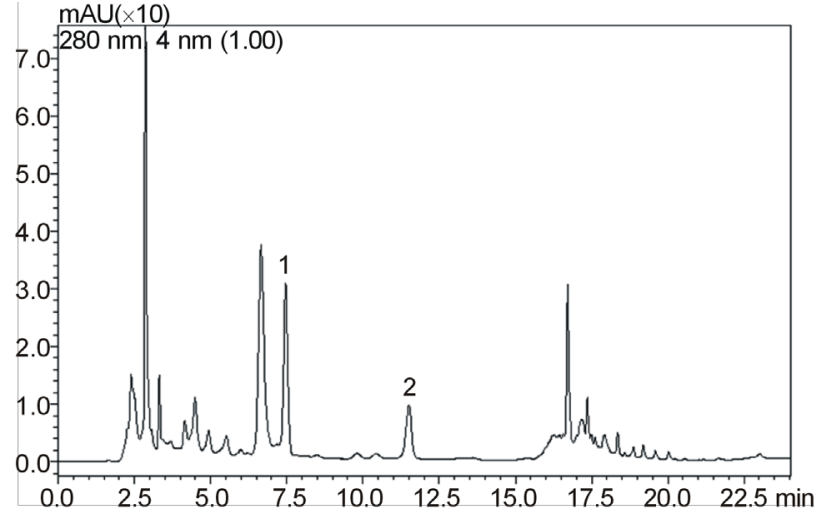

(e)

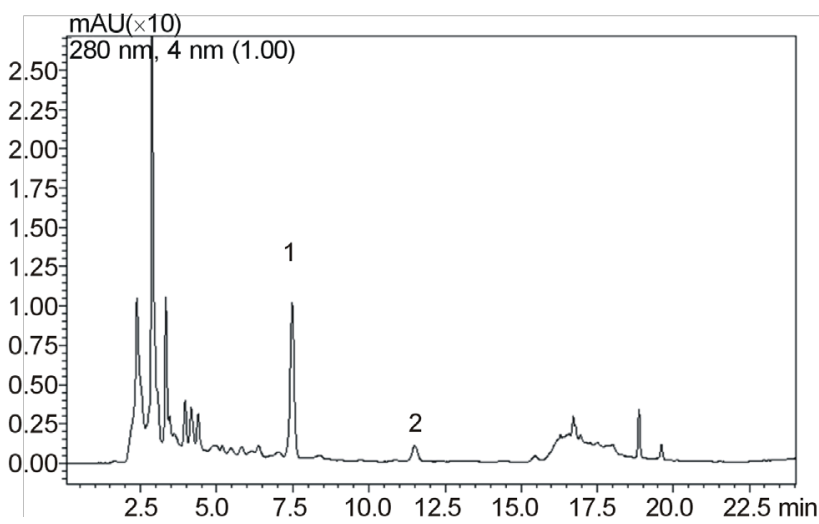

(g)

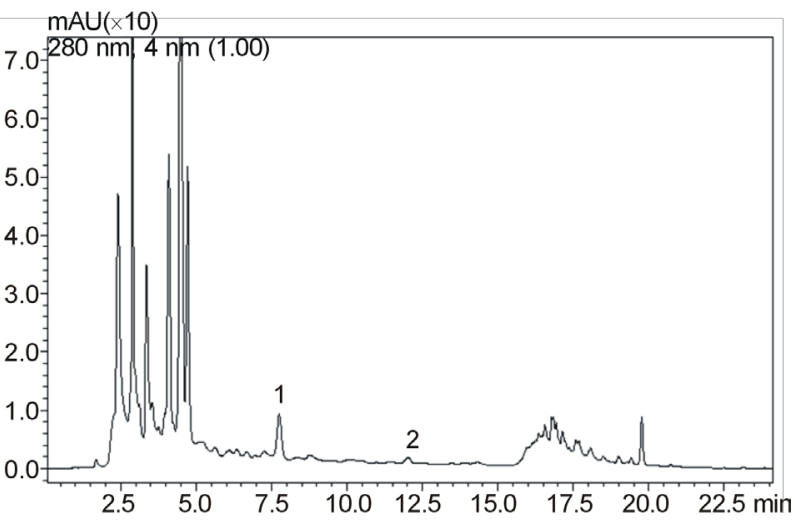

(b)

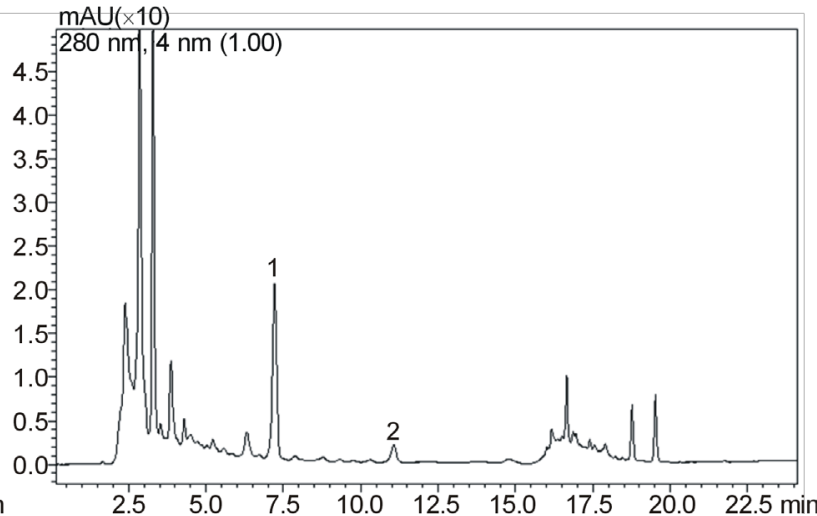

(d)

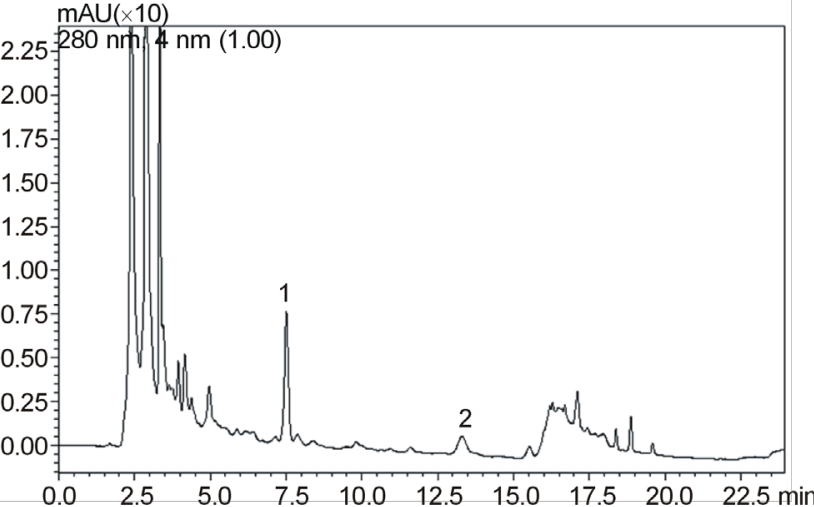

(f)

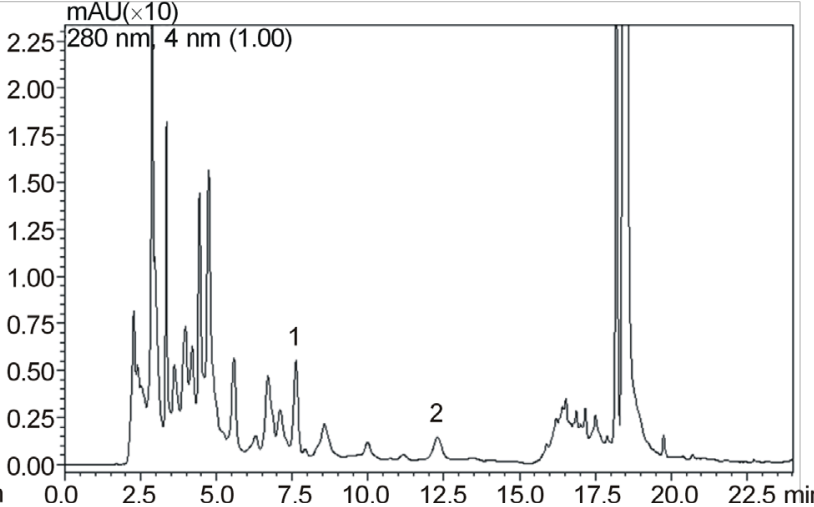

(h) 


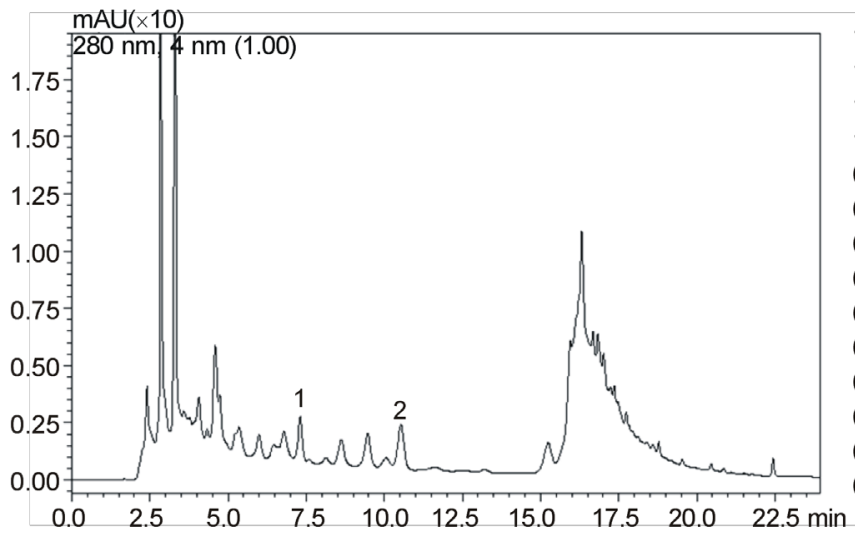

(i)

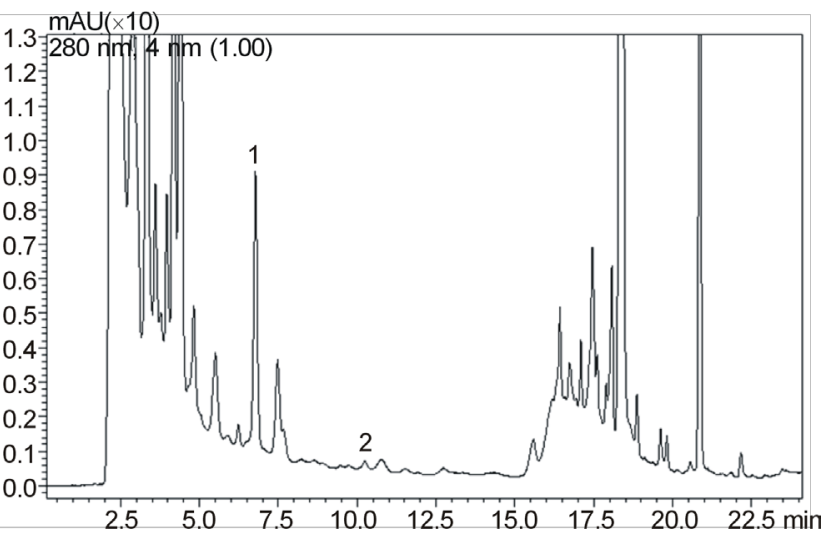

(j)

Figure 4. Chromatographic profiles of wines: Peak 1: Catechin and Peak 2: Epicatechin. Wines of: (a) Pineapple (Ananas comosus L.); (b) Cajá-umbu (Spondias spp.); (c) Cashew apple (Anacardium occidentale L.); (d) Siriguela (Spondias purpurea L.); (e) Mangaba (Hancornia speciosa Gomes); (f) Sugar apple (Annona squamosa L.); (g) Umbu (Spondias tuberosa Arruda Camara); (h) Green grape; (i) Merlot grape; (j) Cashew apple (Anacardium occidentale L.) Siará.

Table 2. Catechin and epicatechin contents in red and white wines produced in industrial scale from fermentation of grapes and cashew apple fruits.

\begin{tabular}{|c|c|c|c|c|}
\hline & \multirow{2}{*}{ Commercial wines } & \multicolumn{3}{|c|}{$\begin{array}{c}\text { Concentration of Flavonols }{ }^{\mathrm{A}} \\
\left(\mathbf{m g} \cdot \mathbf{L}^{-1}\right)\end{array}$} \\
\hline & & Catechin & Epicatechin & Ref \\
\hline \multirow{9}{*}{ 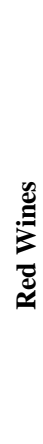 } & Grape Merlot ${ }^{*}$ & $9.39 \pm 0.10$ & $2.52 \pm 0.09$ & - \\
\hline & Cashew apple Siará* & $3.99 \pm 0.26$ & $0.14 \pm 0.07$ & - \\
\hline & Grape Merlot & $9.77 \pm 0.46$ & $2.66 \pm 2.11$ & [8] \\
\hline & Grape Merlot & $10.5 \pm 0.63$ & $57.2 \pm 2.11$ & [27] \\
\hline & Grape Semillion & $13.75 \pm 0.60$ & $11.77 \pm 0.12$ & {$[8]$} \\
\hline & Grape Emir & $3.03 \pm 0.15$ & $1.07 \pm 0.04$ & {$[8]$} \\
\hline & Grape Clairette & $5.83 \pm 0.29$ & $0.54 \pm 0.02$ & [8] \\
\hline & Grape Cinsaut & $10.49 \pm 0.16$ & $1.72 \pm 0.01$ & {$[8]$} \\
\hline & Grape Petty Syrah & $7.51 \pm 0.17$ & $5.08 \pm 0.21$ & [28] \\
\hline \multirow{7}{*}{ 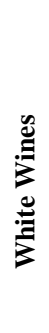 } & Grape Cabernet S. Syrah & $16.73 \pm 0.16$ & $9.99 \pm 0.67$ & [28] \\
\hline & Green Grape* & $3.19 \pm 0.02$ & $3.72 \pm 0.41$ & \multirow{6}{*}{ [29] } \\
\hline & Grape Sauvignon Blanc & 5.9 & NF & \\
\hline & Grape Chenin Blanc & 3.9 & $\mathrm{NF}$ & \\
\hline & Grape Semillon & 5.9 & NF & \\
\hline & Grape Chardonnay & 3.9 & NF & \\
\hline & Grape Sauvignon Blanc & 2.2 & $\mathrm{NF}$ & \\
\hline
\end{tabular}

${ }^{*}$ Results from the present work. ${ }^{\mathrm{A}} \mathrm{N}=4$; $\mathrm{NF}=$ Not Found in Literature.

\section{Conclusion}

The several wines prepared by using different exotic tropical fruit juices (cajá-umbu, cashew apple, mangaba, pineapple, siriguela, sugar apple and umbu) showed the presence of phenolic compounds. The compounds catechin and epicatechin were monitored for their concentrations in tropical fruits wines and commercial wines. Higher contents of catechin and epicatechin were found in wines obtained from mangaba, siriguela and cashew apple when compared to their presence in commercial grape wines.

\section{Acknowledgements}

The authors gratefully acknowledge financial support received from CNPq/INCT-FT and CAPES, Brazil in developing this research project.

\section{REFERENCES}

[1] M. Monagas, B. Bartolome and C. Gomez-Cordoves, "Update Knowledge about the Presence of Phenolic Compounds in Wine," Critical Reviews in Food Science and Nutrition, Vol. 45, No. 2, 2005, pp. 85-118. http://dx.doi.org/10.1080/10408690490911710

[2] J. Gusman, H. Malonne and G. Atassi, “A Repraisal of the Potential Chemopreventive and Chemotherapeutic Properties of Resveratrol," Carcinogenesis, Vol. 22, No. 8, 2001, pp. 1111-1117. http://dx.doi.org/10.1093/carcin/22.8.1111

[3] I. Esparza, C. Santamaría, M. I. Calvo and J. M. Fernández, "Composition and Analysis of Colloidal Matter along Wine-Making," Exploitation of Its Antioxidant Activity in Final Stabilization Residues, Microchemistry Journal, Vol. 91, No. 1, 2009, pp. 32-39. http://dx.doi.org/10.1016/j.microc.2008.07.002

[4] R. Boulton, "The Copigmentation of Anthocyanins and Its Role in the Color of Red Wine: A Critical Review," American Journal of Enology and Viticulture, Vol. 52, No. 2, 2001, pp. 67-87.

[5] P. L. Treissedre, E. N. Frankel, A. L. Waterhouse, H. Peleg and J. B. German, "Inhibition of in Vitro Human LDL Oxidation by Phenolic Antioxidants from Grapes and Wines," Journal of the Science of Food and Agriculture, Vol. 70, No. 1, 1996, pp. 55-61.

[6] C. Auger, N. Al-Awwadi, A. Bornet, J. M. Rouanet, F. 
Gasc, G. Cros and P. L. Teissedre, "Catechins and Procyanidins in Mediterranean Diets," Food Research International, Vol. 37, No. 3, 2004, pp. 233-245. http://dx.doi.org/10.1016/j.microc.2008.07.002

[7] A. S. Meyer, O. S. Yi, D. A. Pearson, A. L. Waterhouse and E. N. Frankel, "Inhibition of Human Low Density Lipoprotein Oxidation in Relation to Composition of Phenolic Antioxidants in Grapes (Vitis vinifera)," Journal of Agricultural and Food Chemistry, Vol. 45, No. 5, 1997, pp. 1638-1643.

[8] O. Gurbuz, D. Goçmen, F. Dagdelen, M. Gursoy, S. Aydin, I. Sahin, L. Buyukuysal and M. Usta, "Determination of Flavan-3-ols and Trans-Resveratrol in Grapes and Wine Using HPLC with Fluorescence Detection,” Food Chemistry, Vol. 100, No. 2, 2007, pp. 518-525. http://dx.doi.org/10.1016/j.foodchem.2005.10.008

[9] A. A. Van der Sluis, M. Dekker, A. de Jager and W. M. F. Jongen, "Activity and Concentration of Polyphenolic Antioxidants in Apple: Effect of Cultivar, Harvest Year, and Storage Conditions," Journal Agriculture Food Chemistry, Vol. 49, No. 8, 2001, pp. 3606-3613. http://dx.doi.org/10.1021/jf001493u

[10] S. H. Häkkinen, S. O. Kärenlampi, H. M. Mykkänen and A. R. Törrönen, "Influence of Domestic Processing and Storage on Flavonol Contents in Berries," Journal of Agricultural and Food Chemistry, Vol. 48, No. 7, 2000, pp. 2960-2965. http://dx.doi.org/10.1021/jf991274c

[11] D. B. Haytowitz, S. Bhagwat and J. M. Holden, "Sources of Variability in the Flavonoid Content of Foods," Procedia Food Science, Vol. 2, 2013, pp. 46-51. http://dx.doi.org/10.1016/j.profoo.2013.04.008

[12] S. M. Araújo, F. C. Silva, J. J. S. Moreira, N. Narain and R. R. Souza, "Biotechnological Process for Obtaining New Fermented Products from Cashew Apple Fruit by Saccharomyces cerevisiae Strains,” Journal of Industrial Microbiology Biotechnology, Vol. 38, No. 9, 2011, pp. 1161-1169. http://dx.doi.org/10.1007/s10295-010-0891-6

[13] P. Viñas, C. López-Erroz, J. J. Marín-Hernández and M. Hernández-Córdoba, "Determination of Phenols in Wines by Liquid Chromatography with Photodiode Array and Fluorescence Detection," Journal of Chromatography A, Vol. 871, No. 1-2, 2000, pp. 85-93. http://dx.doi.org/10.1016/S0021-9673(99)01087-0

[14] A. Aworski and C. Y. Lee, "Fractionation and HPLC Determination of Grape Phenolics," Journal of Agricultural and Food Chemistry, Vol. 35, No. 2, 1987, pp. 257259. http://dx.doi.org/10.1021/if00074a022

[15] J. Oszmianski, T. Ramos and M. Bourzeix, "Fractionation of Phenolics Compounds in Red Wines," American Journal of Enology and Viticulture, Vol. 39, No. 3, 1988, pp. 259-262.

[16] M. P. Serratosa, A. Lopez-Toledano, J. Merida and M. Medina, "Changes in Color and Phenolic Compounds during the Raisining of Grape cv. Pedro Ximenez," Journal of Agricultural and Food Chemistry, Vol. 56, No. 8, 2008, pp. 2810-2816. http://dx.doi.org/10.1021/jf073278k

[17] M. Lopez-Velez, F. Martinez-Martinez and C. Del ValleRibes, "The Study of Phenolic Compounds as Natural
Antioxidants in Wine," Critical Reviews in Food Science and Nutrition, Vol. 43, No. 3, 2003, pp. 233-244. http://dx.doi.org/10.1080/10408690390826509

[18] A. Czyzowska and E. Pogorzelski, "Changes to Polyphenols in the Process of Production of Must and Wines from Blackcurrants and Cherries. Part II. Anthocyanins and Flavanols," European Food Research and Technology, Vol. 218, No. 4, 2004, pp. 355-359. http://dx.doi.org/10.1007/s00217-003-0857-2

[19] M. Bourzeix, D. Weyland and N. Heredia, "Étude des Catéchines et des Procyanidols de la Grape de Raisin, du vin et d'Autres Dérivés de la Vigne,” Bulletin de L'OIV, Vol. 670, 1986, pp. 1175-1254.

[20] V. Katalinic, M. Milos, D. Modun, I. Music and M. Boban, "Antioxidant Effectiveness of Selected Wines in Comparison with (+) Catechin," Food Chemistry, Vol. 86, No. 4, 2004, pp. 593-600. http://dx.doi.org/10.1007/s00217-003-0857-2

[21] M. J. Cejudo-Bastante, M. S. Pérez-Coello and I. Hermosín-Gutiérrez, "Effect of Wine Micro-Oxygenation Treatment and Storage Period on Colour-Related Phenolics, Volatile Composition and Sensory Characteristics," LWT-Food Science and Technology, Vol. 44, No. 4, 2011, pp. 866-874.

http://dx.doi.org/10.1016/j.lwt.2010.10.015

[22] R. M. Orduña, "Climate Change Associated Effects on Grape and Wine Quality and Production,” Food Research International, Vol. 43, No. 7, 2010, pp. 1844-1855. http://dx.doi.org/10.1016/j.foodres.2010.05.001

[23] J. Mulero, F. Pardo and P. Zafrilla, "Effect of Principal Polyphenolic Components in Relation to Antioxidant Activity in Conventional and Organic Red Wines During Storage," European Food Research and Technology, Vol. 229, No. 5, 2009, pp. 807-812. http://dx.doi.org/10.1007/s00217-009-1117-x

[24] T. M. Benassi and M. H. Cecchi, "Caracterização de Vinhos Riesling Nacionais quanto aos Ácidos Carboxílicos e a alguns Compostos Fenólicos,” Vol. 11, Alimentação e Nutrição, São Paulo, 2000, pp. 23-33.

[25] E. Gomez-Plaza, R. Gil-Muñoz, J. M. Lopez-Roca, A. Martinez-Cutillas and J. I. Fernandez-Fernandez, "Phenolic Compounds and Color Stability of Red Wines: Effect of Skin Maceration Time," American Journal of Enology and Viticulture, Vol. 52, No. 3, 2001, pp. 266270.

[26] V. Z. Blanco, J. M. Auw, C. A. Sims and S. F. O’Keefe, "Effect of Processing on Phenolics of Wines," ProcessInduced Chemical Changes in Food, Vol. 434, Plenum Press, New York, 1998, pp. 327-340.

http://dx.doi.org/10.1007/978-1-4899-1925-0 27

[27] A. Marquez, M. P. Serratosa, A. Lopez-Toledano and J. Merida, "Colour and Phenolic Compounds in Sweet Red Wines from Merlot and Tempranillo Grapes Chamber-Dried under Controlled Conditions," Food Chemistry, Vol. 130, No. 1, 2012, pp. 111-120. http://dx.doi.org/10.1016/j.foodchem.2011.07.010

[28] F. S. Dias, M. P. Lovillo, C. G. Barroso and J. M. David, "Optimization and Validation of a Method for the Direct Determination of Catechin and Epicatechin in Red Wines 
by HPLC/Fluorescence,” Microchemical Journal, Vol. 96, No. 1, 2010, pp. 17-20.

http://dx.doi.org/10.1016/j.microc.2010.01.004

[29] D. Fracassetti, N. Lawrence, A. G. J. Tredoux, A. Tirelli, H. H. Nieuwoudt and W. J. Du Toit, "Quantification of
Glutathione, Catechin and Caffeic Acid in Grape Juice and Wine by a Novel Ultra-Performance Liquid Chromatography Method," Food Chemistry, Vol. 128, No. 4, 2011, pp. 1136-1142.

http://dx.doi.org/10.1016/j.foodchem.2011.04.001 